UDC 621.182.11.001.57

V.G. Ahrameev, $\mathrm{PhD}$

Odessa National Polytechnic University, 1 Shevchenko Ave., 65044 Odessa, Ukraine; e-mail: ahvitalchik@ mail.ru

\title{
RESEARCH OF THE SEDIMENT FORMATION INTENSITY AT THE RUN-AROUND COOLING SYSTEMS EQUIPMENT WITH WATER COOLING TOWERS
}

\begin{abstract}
В.Г. Ахрамєєв. Дослідження інтенсивності утворення відкладень на обладнанні оборотних систем охолодження 3 градирнями. Для оборотних систем охолодження найбільш небезпечні забруднення твердими мінеральними відкладеннями, що утворюються внаслідок кристалізації малорозчинних неорганічних солей при переході циркуляційної води в пересичений стан. Mema: Метою роботи є дослідження інтенсивності відкладень кристалів важкорозчинних солей з пересиченою циркуляційної води на поверхнях нагріву випарного охолодження і конденсаторів в оборотних системах охолодження енергоустановок 3 градирнями. Матеріали і методи: Методика проведених досліджень полягала у вимірюванні маси і величини важкорозчинних кристалів в циркуляційній воді і їх відкладень на теплообмінній поверхні конденсатора і випарній поверхні градирні. Вихідна вода для експерименту була відібрана 3 р. Стир. Експериментальні дослідження проводилися на масштабній моделі оборотної системи охолодження. Для вивчення характеру процесів взаємодій частинок твердої фази між собою у вихідній і циркуляційній воді було використано метод дисперсійного аналізу частинок грубодисперсної фази в оптично сканованому шарі води. Результати: Проведено експериментальне дослідження інтенсивності відкладень кристалів важкорозчинних солей з пересиченою циркуляційної води на поверхнях нагріву випарного охолодження і конденсаторів в оборотних системах охолодження енергоустановок 3 градирнями. Визначено, що в міру охолодження циркуляційної води при її стіканні вздовж охолоджуючої поверхні і аерації зустрічним потоком пароповітряної маси відбувається збільшення солевмісту потоку і зростання маси кристалів карбонатних солей, що виділилися; в кінцевому підсумку це призводить до утворення пухких відкладень на необігріваних зрошуючих поверхнях градирень. Виділення центрів кристалізації важкорозчинних карбонатних солей при їх нагріванні в теплообмінних трубках конденсатора відбувається за рахунок термічної дисоціації добре розчинних бікарбонатних солей в важкорозчинні карбонатні солі з наступним відкладенням їх на поверхні трубок, що нагрівається.

Ключові слова: циркуляційна вода, оборотна система охолодження, відкладення.

V.G. Ahrameev. Research of the sediment formation intensity at the run-around cooling systems equipment with water cooling towers. For circulating cooling systems, the solid mineral sediments formed as a result of crystallization of sparingly soluble inorganic salts in the transition of circulating water in the supersaturated state are the most dangerous. Aim: The aim of this research is to study the intensity of sediments of hardly soluble salts crystals on the surfaces of the heating of evaporative cooling equipment and condensers from supersaturated circulating water in the circulating cooling systems of power plants with water cooling towers. Materials and Methods: The methodology of the research was to study the mass and size of the hardly soluble crystals in circulation water and sediments on heat exchange surfaces of the condenser and the evaporator surface of the water cooling tower. Source water for the experiment was selected from Styr river. Experimental studies were carried out at the installation of a scale model of circulation cooling system. To study the nature of the interaction of the solid phase particles with each other in the starting water and the circulating used the method of dispersion analysis of coarse phase particles in the optically scanned water layer. Results: The study the intensity of sediments sparingly of soluble salt crystal on the surfaces of the heating of evaporative cooling equipment and condensers from supersaturated circulating water in the circulating cooling systems of power plants with water cooling towers were held. It has been determined that as the circulation water is cooling, with its runoff along the cooling surface and aeration by counter-steam mass flow there are salinity increase and increase the weight of precipitated carbonate salts crystals, which ultimately leads to the formation of loose sediments in the unheated watering surfaces of water cooling towers. Allocation of crystallization centers of sparingly soluble carbonate salt when it is heated in the heat exchange condenser tubes is due to the thermal dissociation of good soluble bicarbonate salts into sparingly soluble carbonate salts and then sediment at the heated tubes surface.

Keywords: circulating water, circulating cooling system, sediments.
\end{abstract}

Introduction. For circulating cooling systems, the solid mineral sediments formed as a result of crystallization of sparingly soluble inorganic salts in the transition of circulating water in the supersaturated state are the most dangerous. However, a visual inspection of water cooling towers and condensers in Ukrainian power plants shows significant sediments and drifts at the heat exchange surfaces of cooled condensers as well as at the evaporator surfaces of water cooling towers.

Many authors paid attention to the study of the formation sediment process at the heat exchange tubes. Most authors examined the sediments in once-through systems, exploring the water passing through the heat exchanger once [1...5].

\section{DOI 10.15276/opu.2.49.2016.09}

(C) 2016 The Authors. This is an open access article under the CC BY license (http://creativecommons.org/licenses/by/4.0/). 
Briançon [3] and Andritsos [6] considered mainly the dependence of kinetics and mechanisms of sediments, depending on flow multiplicity of the heat exchange tubes surface, ribbing, and the recycling of the circulating water. Also, Andritsos shows that during formation of sediments on rough surfaces the turbulent transport of particles to the heat surface increases and thus decreases the induction period of the process.

Kishnevsky and Chichenin [7] studied the sediments on heat exchange surfaces by using scale inhibitors and without them.

Sediment formation is a complex process involving water supersaturating for salts with nucleation, their transport to the heat exchange surface with the possible sediment. To date, there is no reliable theory of thermodynamic prediction of carbonate salts sediments process on the heat exchange surface. Therefore, most of the known studies based on observational criteria. They allow calculate the probability of formation of sediment on heat exchange surfaces of condensers, but do not consider other types of heat exchangers $[8,9]$.

Practically in all previously published studies in the preparation of the material and salt balance of circulating cooling systems, it was assumed that most of the sediments are crystallized at the heat exchange tubes of condensers

In the works of Kishnevskiy [10] and Garrels [11] there is a studying method of water and chemical mode of circulating cooling systems at the scale model, as well as the possible criterion of sediment formation $\left(\Delta_{C a-A l k}\right)$ is offered, it is assumed that all the solid phase is deposited on the heat exchange surface condencer.

Chichenin [12] proposed a method of the study of the intensity sediments at the coupons without heating the coolant made from the materials typical for heat exchangers in which the heating of coolant is present. At the same time overlooked the processes occurring in the water cooling tower.

In the literature and in the open press author does not found researches aimed at understanding the mechanisms of calcium carbonate crystals sediments on the cooling surface of the water cooling towers and the pipeline surfaces of the run-around cooling systems.

Drifts and sediments at the evaporator surface reduce the operation efficiency of the cooling towers, and, moreover, with significant sediments threaten by major accidents related to the collapse of the irrigation surface.

Thus, study the intensity of sediments at the evaporation part of the water cooling tower and the distribution ratio of sediments mass between the condenser surface and cooling tower surfaces is actually.

The aim of this research is to study the intensity of sediments of hardly soluble salts crystals on the surfaces of the heating of evaporative cooling equipment and condensers from supersaturated circulating water in the circulating cooling systems of power plants with water cooling towers.

To achieve the aim is needed solve the following problems:

- Improve the methodology of research of intensity of sparingly soluble salts sediments on the surface of the cooling tower and evaporative heating surface of condenser.

- Improve the large scale stand of circulation cooling system.

- Carry out the experimental studies at the laboratory stand of large scale cooling system.

Materials and Methods. Formation of carbonate calcium $\mathrm{CaCO}_{3}$ sediments in the cooling tower and the condenser takes place in different thermal and hydraulic conditions:

- in a condenser - at heating of circulating water with the release of $\mathrm{CaCO}_{3}$ on the heated surface; ed surface.

— in a water cooling tower — during cooling water by increasing the salt content on unheat-

Formation of crystallization centers in the circulation water during evaporative cooling in water tower occurs at the "liquid / water-steam mixture" interface.

Allocation of crystallization centers of sparingly soluble carbonate salts during heating of circulating water in the heat exchange tubes of the condenser is due to the thermal decomposition of readily soluble bicarbonate salts with the formation of dense and poorly soluble carbonate salts, and their subsequent sediments onto the heated surface of the tubes. 


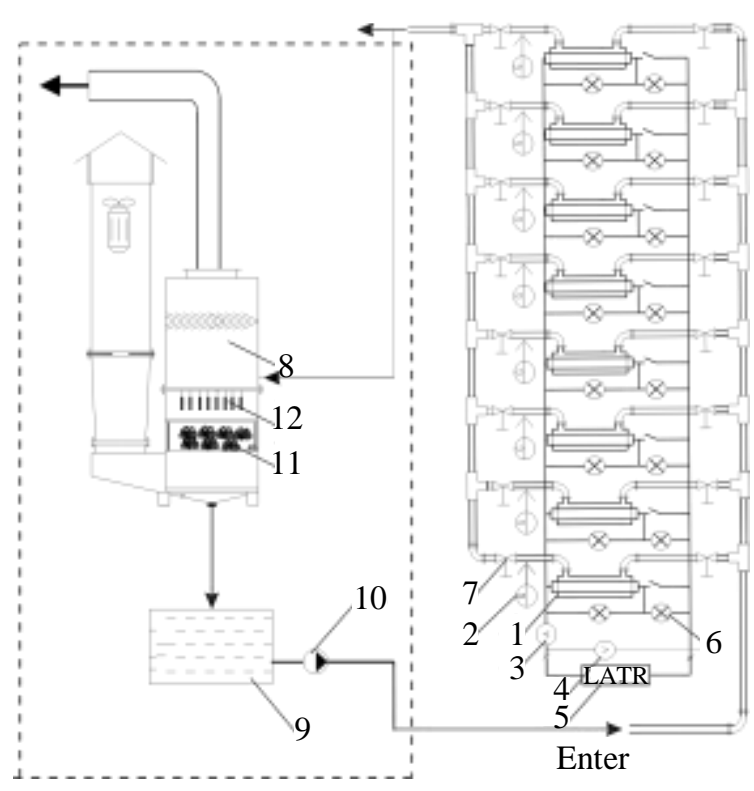

Fig. 1. The model of run-around cooling system: 1 -working cell (heat exchanger with external flow), 2 -flowmeter, 3 -ammeter, 4 -voltmeter, 5 -laboratory transformer (LATR), 6 -indicator, 7 - valve, 8 -water cooling tower, 9 - capacity, 10 - pump, 11 — “crossed wheels" nozzle, 12 - coupons

tower. These elements are designed to compare the growth of sediments in the cooling tower and the condenser on the same materials. Coupons were mounted in the water cooling tower directly under the stream of circulating water dispersed by the nozzle, above the "crossed wheels" nozzle and parallel to air flow.

To control the sediments on the evaporator of the water cooling tower from the nozzle layer were selected and marked 12 elements, connected by a fishing-line.

In operation, the experiment was interrupted after 40 and 100 hours for extraction of nozzle control elements and coupons. Extracted from the installation control elements were placed in a drying oven until dry, then the check weighing held. Detailed sample processing method described in [12].

Control of deposits on the tubes, coupons and cross-disks conducted as weight gain. For elements made of LAMsh, it takes into account the effect of minor corrosion. Kinetics of growth of sediments was investigated in the condenser tubes, coupons and nozzles in a cooling tower.

Characteristics and composition of the source water taken from river Styr the following: $\mathrm{pH}=7.4$, evaporation rate $K_{e}=1$, water alkalinity $A_{w}=1 \mathrm{mgEq} / \mathrm{dm}^{3}$, water hardness $H_{w}=1.9 \mathrm{mgEq} / \mathrm{dm}^{3} ;\left[\mathrm{Cl}^{-}\right]=0.7 \mathrm{mgEq} / \mathrm{dm}^{3},\left[\mathrm{SO}_{4}{ }^{2-}\right]=0.95 \mathrm{mgEq} / \mathrm{dm}^{3}$.

In the pilot study the evaporation rate of the circulating water was maintained at 2 , and $\mathrm{pH}=8$.

Every 12 hours there was sampled for the study of physical and chemical composition of water and the amount of sediments on the controlled areas of the experimental installation at given water velocity and air flow. Humidity, temperature of atmosphere air and air at the outlet of the cooling tower controlled using psychometric analysis.

To study the nature of the interaction processes between the particles of the solid phase in source and circulating water we used the analysis-of-variance method for coarse phase particles in optically scanned water layer, described in detail in [13].

Results. The obtained experimental data for determining the mass of sediment on the coupons, tubes and crossed disks are shown in Tables 1 and 2. 
Table 1

Characteristics of the heat exchange surfaces

\begin{tabular}{c|c|c|c}
\hline Data & Nozzle & Tubes & Coupons \\
\hline Quantity, pcs & 350 & 8 & 3 \\
\hline Area $S, \mathrm{~m}^{2}$ & 0.4613 & 0.02512 & 0.0039 \\
\hline
\end{tabular}

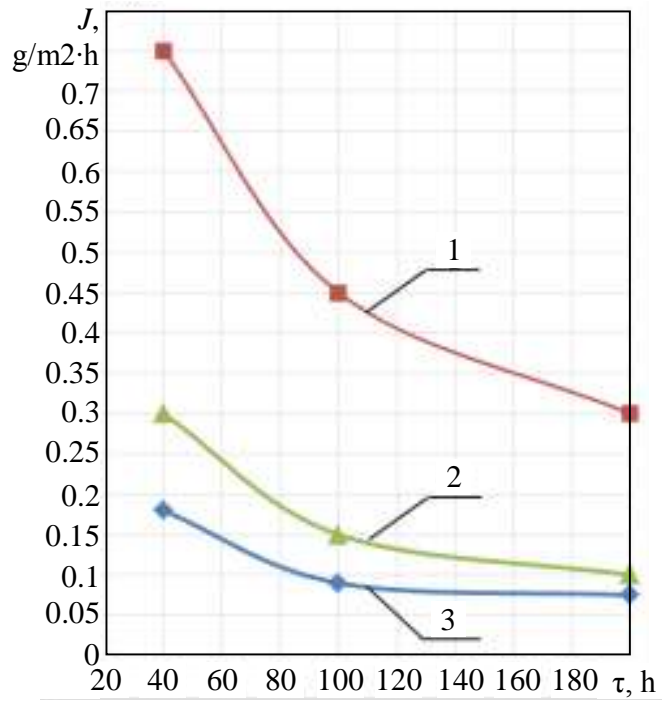

Fig. 2. Dependence of the intensity of sediment on the heat exchange surfaces of water cooling towers and condenser: 1 - LAMsh

brass tube, 2 - LAMsh brass coupons, 3 - polyethylene nozzles
Mass of sediment on heat exchange surfaces

\begin{tabular}{c|c|c|c}
\hline \multirow{2}{*}{ Time, hour } & \multicolumn{3}{|c}{ Sediments mass, $\mathrm{g}$} \\
\cline { 2 - 4 } & Nozzles & Tubes & Coupons \\
\hline 40 & 3.32136 & 0.7536 & 0.000288 \\
\hline 100 & 4.1517 & 1.1304 & 0.00036 \\
\hline 200 & 6.9195 & 1.5072 & 0.00048 \\
\hline
\end{tabular}

Visual inspection shows that the sediments in the water cooling towers are loose; moreover, the adhesion between the sediments and the heat exchange surfaces is flimsy.

Dependences of the intensity of sediments on the heating surfaces of the condenser, nozzles and control coupons considering the density of carbonate salts are shown in Fig. 2.

The intensity of sediments on the heated heat exchanger surface of the condenser tubes was $0.75 \mathrm{mg} /\left(\mathrm{m}^{2} \cdot \mathrm{h}\right)$ after 40 hours after the start of the experiment, and $0.30 \mathrm{mg} /\left(\mathrm{m}^{2} \cdot \mathrm{h}\right)$ - after 200 hours. The intensity of sediments on the unheated surface in the water cooling tower for LAMsh brass coupons was 0.30 and $0.10 \mathrm{mg} /\left(\mathrm{m}^{2} \cdot \mathrm{h}\right)$, respectively.

Thus, the intensity of sediment in the condenser is different from the intensity in the water cooling tower in more than two times, provided that they are made of the same material (LAMsh).

The intensity of sediments on the unheated surface in the water cooling tower on the polyethylene nozzles was $0.170 \mathrm{mg} /\left(\mathrm{m}^{2} \cdot \mathrm{h}\right)$ at the beginning of the experiment, and $0.07 \mathrm{mg} /\left(\mathrm{m}^{2} \cdot \mathrm{h}\right)$ at the end. This is a few less than for LAMsh brass coupons, but the difference is not so significant.

Conclusions. The conducted research lead to the conclusion that the processes of formation of carbonate salt sediments in the water cooling tower and in the condenser determined by the heathydraulic conditions.

The obtained experimental data indicate that the intensity of sediments on the heat exchanger surface of the condenser tubes is more than two times higher than on the control coupons of irrigated surface of the water cooling towers made of LAMsh brass. Furthermore, it is shown that the intensity of sediments on unheated surface of LAMsh brass coupons is higher than on the polyethylene nozzles by $30 . . .40 \%$.

\section{Література}

1. Исследование дисперсного состава и характеристик твердофазных частиц в циркуляционной воде оборотных систем охлаждения / А.Б. Гуляенко, Е.В. Кишневский, О.М. Малиновский, В.Ф. Очков // Пр. Одес. політехн. ун-ту. — 2010. — Вип. 1(33)-2(34). - С. 70-75.

2. Кишневский, В.А. Предотвращение коррозии паровых калориферов и их конденсатопроводов / В.А. Кишневский, А.П. Боровский, Б.Н. Шукайло // Пр. Одес. політехн. ун-ту. — 2005 . Вип. 2(24). - С. 90-95. 
3. Неведров, А.В. Сравнительный анализ физических методов обработки воды для уменьшения накипеобразования / А.В. Неведров, Г.В. Ушаков // Теплоэнергетика. — 2003. — № 11. — С. 6264.

4. Calcium carbonate deposit formation under isothermal conditions / N. Andritsos, M. Kontopoulou, A.J. Karabelas, P.G. Koutsoukos // The Canadian Journal of Chemical Engineering. — 1996. — Vol. 74, Issue 6. - PP. 911-919.

5. Kazi, S.N. Fouling and fouling mitigation on heated metal surfaces / S.N. Kazi, G.G. Duffy, X.D. Chen // Desalination. - 2012. - Vol. 288. - PP. 126-134.

6. Andritsos, N. Morphology and structure of $\mathrm{CaCO}_{3}$ scale layers formed under isothermal flow conditions / N. Andritsos, A.J. Karabelas, P.G. Koutsoukos // Langmuir. - 1997. — Vol. 13, Issue 10. PP. 2873-2879.

7. Briançon, S. Modelling of crystalline layer growth using kinetic data obtained from suspension crystallization / S. Briançon, D. Colson, J.P. Klein // Chemical Engineering Journal. — 1998. — Vol. 70, Issue 1. - PP. 55-64.

8. Kostoglou, M. Comprehensive modeling of precipitation and fouling in turbulent pipe flow / M. Kostoglou, A.J. Karabelas // Industrial \& Engineering Chemistry Research. — 1998. — Vol. 37, Issue 4. - PP. 1536-1550.

9. Karabelas, A.J. Scale formation in tubular heat exchangers - research priorities / A.J. Karabelas // International Journal of Thermal Sciences. — 2002. - Vol. 41, Issue 7. - PP. 682-692.

10. Кишневский, В.А. Исследование процессов карбонатных отложений на теплообменных поверхностях конденсаторов / В.А. Кишневский, В.В. Чиченин // Восточно-Европейский журнал передовых технологий. - 2014. - № 3/8 (69). - С. 52-58.

11. Garrels, R.M. Solutions, minerals, and equilibria / R.M. Garrels, C.L. Christ. — Boston: Jones and Bartlett, 1990. - 450 p.

12. Исследование скорости коррозии и накопления отложений при упаривании циркуляционной воды в лабораторных условиях / В.В. Чиченин, В.А. Кишневский, А.С. Грицаенко и др. // Восточно-Европейский журнал передовых технологий. - 2015. - № 5/8 (77). — С. 14-20. DOI:10.15587/1729-4061.2015.51205

13. Кишневский, В.А. Методика расчета водно-химического режима комплексной оборотной системы охлаждения с рециркуляцией / В.А. Кишневский, В.В. Чиченин, И.Д. Шуляк // ВосточноЕвропейский журнал передовых технологий. - 2013. - № 6/8 (66). - С. 10-14.

\section{References}

1. Guliayenko, A.B., Kishnevsky, E.V., Maleenovsky, O.M., \& Ochkov, V.F. (2010). Research of dispersion composition and characteristics of solid-phase particles in circulation water of the circulating systems of cooling. Odes 'kyi Politechnichnyi Universytet. Pratsi, 1-2, 70-75.

2. Kishnevsky, V.A., Borovsky, O.P., \& Shukaylo, B.N. (2005). Prevention of corrosion in steam air heaters and their condensate pipes. Odes 'kyi Politechnichnyi Universytet. Pratsi, 2, 90-95.

3. Nevedrov, A.V., \& Ushakov, G.V. (2003). A comparative analysis of physical methods for water treatment to reduce scale formation. Thermal Engineering, 50(11), 944-947.

4. Andritsos, N., Kontopoulou, M., Karabelas, A.J., \& Koutsoukos, P.G. (1996). Calcium carbonate deposit formation under isothermal conditions. The Canadian Journal of Chemical Engineering, 74(6), 911-919. DOI:10.1002/cjce.5450740614

5. Kazi, S.N., Duffy, G.G., \& Chen, X.D. (2012). Fouling and fouling mitigation on heated metal surfaces. Desalination, 288, 126-134. DOI:10.1016/j.desal.2011.12.022

6. Andritsos, N., Karabelas, A.J., \& Koutsoukos, P.G. (1997). Morphology and structure of $\mathrm{CaCO}_{3}$ scale layers formed under isothermal flow conditions. Langmuir, 13(10), 2873-2879. DOI:10.1021/la960960s

7. Briançon, S., Colson, D., \& Klein, J.P. (1998). Modelling of crystalline layer growth using kinetic data obtained from suspension crystallization. Chemical Engineering Journal, 70(1), 55-64. DOI:10.1016/S1385-8947(98)00080-1

8. Kostoglou, M., \& Karabelas, A.J. (1998). Comprehensive modeling of precipitation and fouling in turbulent pipe flow. Industrial \& Engineering Chemistry Research, 37(4), 1536-1550. DOI: 10.1021/ie970559g 
9. Karabelas, A.J. (2002). Scale formation in tubular heat exchangers - research priorities. International Journal of Thermal Sciences, 41(7), 682-692. DOI:10.1016/S1290-0729(02)01363-7

10. Kishnevsky, V., \& Chichenin, V. (2014). Study of carbonate deposits on heat exchange surfaces of condensers. Eastern-European Journal of Enterprise Technologies, 3(8), 52-58.

11. Garrels, R.M., \& Christ, C.L. (1990). Solutions, Minerals, and Equilibria. Boston: Jones and Bartlett.

12. Chichenin, V., Kishnevskiy, V., Hrytsaienko, A., Ahrameev, V., \& Shuliak, I. (2015). Study of corrosion rate and accumulation of deposits under circulating water concentration in bench experiments. Eastern-European Journal of Enterprise Technologies, 5(8), 14-20. DOI:10.15587/17294061.2015.51205

13. Kishnevskiy, V., Chichenin, V., \& Shulyak, I. (2013). Method of calculation of water chemistry of the integrated circulation cooling system with recirculation. Eastern-European Journal of Enterprise Technologies, 6(8), 10-14. 